\title{
A Bewitching Beauty of the "Bad-Lands"
}

By ARCHIE BUDD, Swift Current

The so-called "bad-lands" of our southern prairies have a most interesting flora and here are found several species not often seen elsewhere. One of the most beautiful of these is the Evening Star, sometimes called the Gumbo Lily or Showy M e nt zeli a, Mentzelia decapetala (Pursh) Urban \& Gilg. This is a biennial plant from 6 to 24 inches in height, with rough, grayish green stems and leaves. The leaves are sharply and coarsely toothed, varying from 2 to 6 inches in length, and very rough to the touch. The upper leaves are stalkless while the lower are frequently short stalked.

The flowers are borne at the ends of the branches and when fully open may be well over 3 inches across and appear in June and July. As they only open in the evenings their full beauty is rarely seen; generally they appear with closed flowers, resembling short white candles on a miniature Christmas Tree. They appear to have ten creamy-white petals, only five of which are true petals, the others being petaloid, sterile stamens. In the centre of each flower is a dense cluster of from two to three hundred stamens and the flower has a somewhat cactus-like appearance.
The fruit are capsules about one and a half inches long and half an inch across and open at the top when mature releasing the numerous flat seeds. The seeds of a closely related species, Mentzelia albicaulis, were ground and pounded into a kind of cake and eaten by the Indians of Montana and Oregon.

This is the only Saskatchewan species of the Loasa family and is found in the "bad-lands" of the southern part of the Province, particularly near Eastend and the valleys adjoining the Frenchman River, the Big Muddy Lake area, around Roche Percee and also on the clay banks of the South Saskatchewan River near Estuary. Seeing this beautiful plant growing in such wild and deserted locations one is reminded of a portion of Gray's Elegy, "Full many a flower is born to blush unseen and waste its' sweetness on the desert air." The scientific generic name, Mentzelia, is dedicated to a German botanist of the seventeenth century, Christian Mentzel, and the specific name, decapetala, signifies its apparent ten petals. By the botanist Greene it was placed into a separate genus, Nuttallia, but modern taxonomists retain it in the Linnaean genus of Mentzelia.

\section{Flooded Out-But Survived}

\author{
By ED WILEY, Saltcoats
}

Now that spring is here, we are looking forward to renewing acquaintances with many of our feathered friends that have spent their rather prolonged winter vacation in the sunny South. It is interesting to look back a few short months and remember the struggle some of them had to reproduce their species under adverse weather conditions.

We had several duck nests under observation but will tell about only one. This mallard had her nest quite near our stable in a bunch of willows on a little island about six feet across. There were nine eggs about half incubated when the rains became more frequent and heavier. The water was rising and coming nearer and nearer to the eggs.

One duck sensed danger and began to raise her nest by putting twigs, sticks and leaves under the eggs. We were never able to see her working, as she was always on the nest when we went to look. The situation looked hopeless to us. The eggs were very wet and resting on sticks instead of downs.

Eventually the weather became a little nicer. The duck which was getting quite well acquainted with us by this time, got her nest into pretty fair shape again. When the time came, out came the little ducklings (Continued on Page 21) 